\title{
Cotton Stalk Compost as a Substitution to Farmyard Manure Along with Mineral Fertilizers and Microbials Enhanced Bt Cotton Productivity and Fibre Quality in Rainfed Vertisols
}

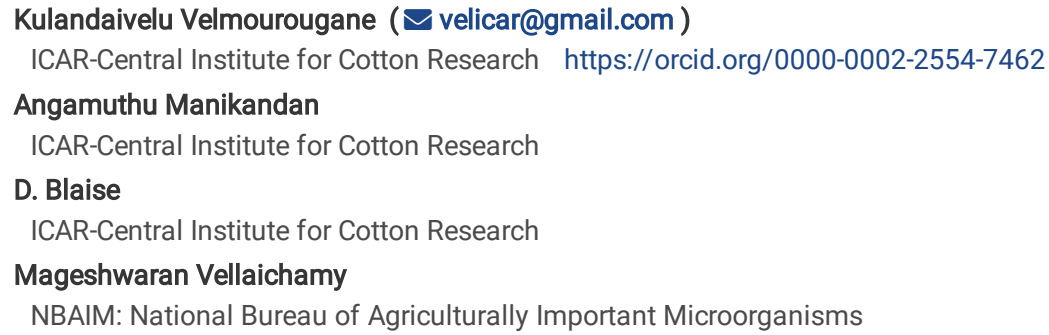

\section{Research Article}

Keywords: cotton stalk compost, cotton yield, fibre quality, soil health, nutrient availability, economics

Posted Date: August 30th, 2021

DOI: https://doi.org/10.21203/rs.3.rs-780420/v1

License: (c) (1) This work is licensed under a Creative Commons Attribution 4.0 International License. Read Full License

Version of Record: A version of this preprint was published at Waste and Biomass Valorization on January 30th, 2022. See the published version at https://doi.org/10.1007/s12649-022-01689-x. 


\section{Abstract}

Cotton stalks, remaining after the cotton is harvested, are considered waste material and disposed of by burning. Presently, the supply of good quality manure, such as farmyard manure (FYM) is low. Thus, recycling of cotton stalks as compost can reduce the dependency on FYM apart from reducing inorganic fertilizer use and soil health enhancement. Some studies have reported on the conversion of cotton ginnery wastes into organic manure. However, no studies have reported about the composting of cotton stalks. We conducted field studies over three years on Vertisols to evaluate the impact of integrated use of microbially enriched cotton stalk compost (ECC) as an alternative to FYM along with mineral fertilizers in cotton production. Additionally, we evaluated an option of using native microbial consortia as seed treatment and their synergistic effect along with ECC application on cotton yield, fibre quality, and soil properties. Results indicated that the substitution of FYM with ECC in integrated nutrient management (INM) produced effects similar to that of FYM use in enhancing cotton yield and soil properties. Application of ECC + inorganic fertilizers (modified nutrient management practice) in soil increased boll numbers (8.4\%), boll weight (9.9\%), seed cotton yield (13\%), fibre properties, soil nutrient, and biological activities, which were on par with FYM + inorganic fertilizer application. The use of ECC is estimated to reduce $50 \%$ costs on nitrogenous, phosphatic, and potassic fertilizers, and can save approximately US\$ 34 ha ${ }^{-1}$ on inorganic and manures in the recommended dose of fertilizers (RDF) and INM practice.

\section{Highlights}

- There is a huge shortage of farmyard manure (FYM) for cotton cultivation

- Recycling of cotton stalks as compost (ECC) can depose the dependency on FYM

- Substitution of FYM with ECC produced similar effects on cotton yield and fibre

- Application of ECC enhanced the soil physico-chemical and biological health

- Use of ECC reduced the costs on the inorganic nutrients by US\$20-25 ha-1

\section{Statement Of Novelty}

There is a short supply of organic manures (especially farmyard manure) for cotton farming due to increased adoption of mechanization in agriculture. For the first time, through three years field study, we demonstrated the utility of cotton stalk compost as an alternative to farmyard manure in $B t$-cotton production, without affecting the cotton yield, fibre quality, nutrient availability, and soil biological activities in vertisols

\section{Introduction}

Agricultural crop residues are the most promising and renewable feedstock materials for several agricultural and industrial applications [1]. Among agricultural biomass, lignocellulosics represent a huge potential for generating high-value products [2]. However, farmers most often consider the cotton crop residue as a major hindrance in farm operations and dispose it off by burning [3]. There is a growing concern regarding land degradation and associated atmospheric pollution following burning of the crop residues [4]. Furthermore, inappropriate use of fertilizers is common in the rainfed regions in central India. Application rates in amounts greater than those recommended by research stations is done by the rich farmers; while the poor farmers apply less than the recommended rates of fertilizers. As a result, soils have begun showing signs of nutrient exhaustion and subsequent decline in crop productivity [5]. Apart from the fertilizers, it is essential to apply manures to sustain potential crop yields [6]. However, the cost of fertilizer and manure alone contributes to $9.6 \%$ and $3.2 \%$, respectively, of the total cost of cultivation in India [7]. This has prompted researchers to search for alternatives to synthetic fertilizers is imperative considering increasing costs of fertilizers and the importance of maintaining the biological soil productivity producing a safer produce sustainably [8,9]. Although, alternate approaches such as crop residue recycling and green manuring are recommended, most often, agricultural crops are grown without recycling of waste generated on the farm. On a long-term basis, this practice creates soil nutrient imbalance [10]. In such situations, the volume of agricultural waste, which is presently treated as an environmental pollutant can be, very well used as a feedstock for on-farm production of organic manure and returning of these wastes as bioenriched compost, will improve soil nutrient status especially the soil organic matter [11, 12].

Though several million tons of cotton wastes are generated worldwide annually, most of these wastes are not valorized scientifically, especially in developing countries, damaging the soil, environment, and economy [13]. Cotton wastes are broadly classified into on-farm and off-farm wastes. On-farm wastes mainly constitute cotton stalks and other plant parts, including roots, leaves, carpels, etc. While, off-farm wastes comprise cotton gin trash and cottonseed byproducts, including whole cotton seeds, cotton meal (seed kernel), cotton linters, etc. [14]. Although cotton stalks are seasonal wastes, approximately $3-5$ $\mathrm{Mg}$ stalks are available per hectare [15]. Off late, due to the stringent environmental regulations, the disposal of cotton wastes has become a biggest problem for cotton growers and ginners. Furthermore, there is a short supply of organic manures (especially farmyard manure (FYM)) for cotton farming due to increased adoption of mechanization in agriculture [7]. Largely, farmers have stopped the application of organic manure in their farm lands due to nonavailability of organic manure at farm level. Non-application of organic manure along with low organic carbon levels in soils has made the semi-arid regions a less fertile land. Additionally, due to the low soil organic carbon content $(<0.5 \%)$, the soil health in terms of physical, chemical and biological functions is adversely affected, apart from reducing crop productivity [16].

At present, a small quantum of cotton stalks generated is used for the production of value-added products (particle boards, pulp and paper making, briquetting), and the remaining bulk of the stalks is burned off in the fields after harvest [17], leading to huge loss of nutrients from soils extracted by the cotton stalks, deteriorating soil health and causing environmental pollution [18]. Since cotton stalks have high lignin content (20\%-22\%), it does not degrade under field conditions (in situ composting) easily. Direct application of cotton stalks as chipped form without making proper compost immobilizes soil nutrients making them unavailable for subsequent crops. Further, the accumulation of cotton residue at farms creates problems of rodents, pest (pink bollworms) and disease (root rots) intensity [18]. Hence, there is an urgent need for an alternative viable technology for the effective use of cotton wastes at 
the farm level, and to control environmental pollution. Due to greater awareness and concern about environmental health of long-term chemical use, recently, organics and microbial technologies are increasingly used in agriculture and environment to mobilize unavailable plant nutrients, management of pests and diseases, product quality improvements, and soil health management [19]. In agriculture, the application of microbial or nutrient-enriched compost enhanced soil fertility status in terms of physical, chemical, and biological attributes leading to enhanced crop productivity [20]. Composting offers a suitable and viable option for cotton waste usage since the process does not affect the environment, and recycles the nutrients in the soil, leading to a sustainable cotton production [21,22]. Additionally, on-farm composting is expected to bring down the dependency on inorganic fertilizers for cotton production, apart from the safe disposal of cotton wastes protecting the environment [10].

Though several studies reported the conversion of cotton ginnery wastes into organic manure [23, 24], few reported on cotton stalk compost [25]. Further, there are no long-term field studies with respect to the use of cotton stalk compost and its effect on cotton yield, fibre properties, and soil biological properties.

Though, microbial seed treatment (Azotobacter spp.) of cotton seeds is a recommended practice, in general, cotton farmers do not adopt this practice [26, 27] Hence, we evaluated the impact of integrated use of microbially enriched cotton stalk compost (ECC) as an alternative to FYM along with mineral fertilizers in rainfed cotton production. Additionally, we evaluated the benefits of native microbial consortia as a seed treatment option in cotton and studied their synergistic effect along with ECC on seed cotton yield (SCY), fibre quality, and soil properties with the hypothesis that the substitution of FYM with microbially enriched ECC along with microbial seed treatment may bring down the dependency on FYM besides improvements in cotton and soil productivity.

\section{Materials And Methods}

\section{Enriched cotton stalk compost preparation}

The microbially enriched cotton stalk compost for the study was obtained from ICAR-Central Institute for Research on Cotton Technology (CIRCOT), Nagpur. The cotton stalk compost was prepared by aerobic method using chipped cotton stalks $(2-3 \mathrm{~cm})$ and inoculating ligno-cellulosic and plant growth-promoting microorganisms. Cow dung (10\%) and farm soil (0.1\%) were added to hasten the composting process. The compost heap was prepared following the layering method, with the addition of inoculum @ 0.1\% (Bacillus stearothermophilus, Pleurotus flabellatus and Phanerochaete chrysosporium obtained from Microbiology section, CIRCOT, Mumbai), urea (1.2\%) and rock phosphate (2\%) to supplement nitrogen and phosphorus for the composting microbes. The composting heap was sufficiently moistened ( 60\%), and the composting heaps were covered with plastic sheets to conserve heat and avoid ammonia volatilization. The composting process was monitored periodically by sprinkling water and regular turnings. After 30 days of composting, the partially composted biomass was inoculated with selected plant growth-promoting microorganisms (Phosphobacteria, Azospirillum, Azotobacter, Trichoderma viride and Pseudomonas fluorescens) @ $1 \mathrm{~kg}$ inoculum with a cell load of $10^{10} \mathrm{~g}^{-1}$ for each bacterium for five tons of cotton stalks. After maturation (90-110 days), the bioenriched compost was sieved and stored for further use. The prepared ECC composition (dry weight basis) is as follows: $\mathrm{pH}$ (7.5), organic carbon (20\%), nitrogen (1.6\%), phosphorus $(0.8 \%)$, potassium (1.5\%), iron $\left(1.27 \mathrm{mg} \mathrm{kg}^{-1}\right)$, manganese $\left(44 \mathrm{mg} \mathrm{kg}^{-1}\right)$, and zinc $\left(263 \mathrm{mg} \mathrm{kg}{ }^{-1}\right)$.

\section{Microbial consortia for seed treatment}

The microbial consortia for cotton seed treatment were prepared using the following native bacterial isolates identified from the cotton rhizosphere (Bacillus subtilis (NAIMCC-B-02312); Bacillus mojavensis (NAIMCC-B-02307); Pseudomonas putida (NAIMCC-B-02309); Pseudomonas sp. (NAIMCC-B-02314); Enterobacter hormaechei (NAIMCC-B-02308)). These bacterial isolates were short-listed based on their nutrient solubilization (phosphorus and potassium) and other plant growth promoting attributes (IAA production and 1-aminocyclopropane-1-carboxylic acid (ACC) deaminase activity) (Table 1). Bt- cotton seed (Bunny BGII hybrid; Gossypium hirsutum L.) was surface sterilized (5min soaking in $1 \%$ sodium hypochlorite) before seed treatment. The bacterial isolates were individually grown for $48 \mathrm{~h}$ in Nutrient broth, and mixed together as consortia at the time of seed treatment. The cotton seeds were coated with the microbial consortia @ $5 \mathrm{~mL} \mathrm{~kg}^{-1}$, such that the CFU (colony forming units) per seed to have $10^{8}-10^{9}$ using $0.5 \%$ carboxy methyl cellulose as a seed-coating agent. The microbially coated seeds were air dried in shade for $1 \mathrm{~h}$ before sowing.

Table 1 Microbial consortia used for cotton seed treatment and their plant growth promoting attributes

\begin{tabular}{|c|c|c|c|c|c|c|c|}
\hline \multirow{2}{*}{$\begin{array}{l}\text { Bacterial isolates } \\
\text { (Accession number) }\end{array}$} & \multicolumn{3}{|c|}{ Phosphorus and phosphatase activity } & \multicolumn{2}{|c|}{ Potassium solubilization } & \multicolumn{2}{|c|}{ Growth promotion and biocontrol } \\
\hline & $\begin{array}{l}\text { Soluble P } \\
\left(\mathrm{mg} \mathrm{mL}^{-1}\right)\end{array}$ & $\begin{array}{l}\text { Acid-P } \\
\left(\mu g \mathrm{PNP} \mathrm{g}^{-1} \mathrm{~h}^{-1}\right)\end{array}$ & $\begin{array}{l}\text { Akl-P } \\
\left(\mu g \operatorname{PNP~g}^{-1} \mathrm{~h}^{-1}\right)\end{array}$ & $\begin{array}{l}\text { K-Muscovite } \\
\left(\mathrm{mg} \mathrm{kg}^{-1}\right)\end{array}$ & $\begin{array}{l}\text { K-Illite } \\
\left(\mathrm{mg} \mathrm{kg}^{-1}\right)\end{array}$ & $\begin{array}{l}\text { IAA } \\
\left(\mu g \mathrm{~mL}^{-1}\right)\end{array}$ & $\begin{array}{l}\text { ACCD } \\
\left(\text { nmoles g }^{-1}\right)\end{array}$ \\
\hline $\begin{array}{l}\text { Bacillus subtilis } \\
\text { (NAIMCC- B-02312) }\end{array}$ & 3.2 & 53 & 31 & 73.3 & 180.0 & 4.3 & 910.3 \\
\hline $\begin{array}{l}\text { Bacillus mojavensis } \\
\text { (NAIMCC- B-02307) }\end{array}$ & 2.6 & 67 & 9 & 48.7 & 253.3 & 0.7 & 812.5 \\
\hline $\begin{array}{l}\text { Pseudomonas putida } \\
\text { (NAIMCC- B-02309) }\end{array}$ & 2.1 & 103 & 93 & 210.0 & 243.3 & 4.7 & 417.0 \\
\hline $\begin{array}{l}\text { Enterobacter hormaechei } \\
\text { (NAIMCC- B-02308) }\end{array}$ & 2.7 & 54 & 29 & 62.4 & 192.5 & 2.0 & 725.4 \\
\hline $\begin{array}{l}\text { Pseudomonas sp. } \\
\text { (NAIMCC-B-02314) }\end{array}$ & 4.6 & 51 & 32 & 54.0 & 263.3 & 1.5 & 346.2 \\
\hline
\end{tabular}


Field experiments (three years) were conducted at ICAR-Central Institute for Cotton Research, Panjri Farm, Nagpur ( $21^{\circ} 04^{\prime} 71^{\prime \prime} \mathrm{N}$ and $\left.79^{\circ} 04^{\prime} 40^{\prime \prime} \mathrm{E}\right)$ in Central India. The Panjari farm is situated at $309 \mathrm{M}$ above the mean sea level and has a mean annual rainfall of $1026 \mathrm{~mm}$. Soil at the experimental site belongs to deep black Vertisol (Typic Haplusterts) classified as sub humid moist bioclimate (10.2) under Agro-ecological sub-regions of India. The soil is low in organic carbon $(0.48 \%)$, low in available nitrogen $\left(176 \mathrm{~kg} \mathrm{ha}^{-1}\right)$, medium in available phosphorus $\left(14.5 \mathrm{~kg} \mathrm{ha}^{-1}\right)$, and high in exchangeable potassium $\left(503 \mathrm{~kg} \mathrm{ha}^{-1}\right)$ with a slightly alkaline reaction $(\mathrm{pH} 7.54)$.

\section{Experimental setup and treatments}

The Bt-cotton hybrid (Bunny BGIIß) was sown manually with the onset of the monsoon in June, with a spacing of $60 \times 60 \mathrm{~cm}$ using a line marker. The field experiments were arranged in a two- factorial randomized block design with two main treatments and six sub-plot treatments. The main treatments included seed treatment with or without microbial consortia. The six sub-treatments were 1) Recommended dose of fertilizers (RDF, $90 \mathrm{~kg} \mathrm{~N}: 19 \mathrm{~kg} \mathrm{P:} 37 \mathrm{~kg} \mathrm{~K} \mathrm{ha}{ }^{-1}$ ), 2) Integrated Nutrient Management practice (INM, $60 \mathrm{~kg} \mathrm{~N}: 13 \mathrm{~kg} \mathrm{P:} 25 \mathrm{~kg} \mathrm{~K} \mathrm{ha}^{-1}$ along with $5 \mathrm{Mg}$ farmyard manure (FYM)), 3) Modified Integrated Nutrient Management practice (MINM, $60 \mathrm{~kg} \mathrm{~N}: 13 \mathrm{~kg} \mathrm{P:} 25 \mathrm{~kg} \mathrm{~K} \mathrm{ha}^{-1}+5 \mathrm{Mg}$ of Microbially Enriched Cotton stalk Compost (ECC)), 4) Farmyard manure (5 Mg ha-1), 5) Enriched cotton stalk compost $\left(5 \mathrm{Mg} \mathrm{ha}^{-1}\right)$, and 6 ) Control (No nutrients). The recommended dose of fertilizers was based on the standard nutrient management practice for the rainfed cotton in Central India. The FYM and ECC were applied as basal, while, the chemical fertilizers were applied in split doses according to the recommended practice for rainfed cotton ( $\mathrm{N}$ in 3 splits viz., $50 \%$ as basal, $25 \%$ during squaring, $25 \%$ during flowering; full dose of $\mathrm{P}$ and $\mathrm{K}$ as basal; micronutrients $(0.5 \%)$ as foliar before flowering). In all the treatments, recommended agronomic, nutrient, and pest management practices were followed (Blaise and Kranthi, 2019).

\section{Soil physico-chemical analysis}

The soil physical and chemical parameters were analyzed at the peak boll formation stage (100 days after sowing) of the cotton crop. For analysis, the soil samples in triplicates were collected from the inter-planting lines at 0-30 cm depth from the representative treatments. The bulk density (BD) was determined by a field-moist method using core samples (diameter $50 \mathrm{~mm}$ ) of known volume $\left(100 \mathrm{~cm}^{3}\right)$ [28]. The $\mathrm{CaCO}_{3}$, pH (1:2) were determined on the total fine earth $(<2 \mathrm{~mm}$ ) by standard methods [29]. Walkley and Black wet digestion method was followed to quantify organic carbon (OC) content in the samples. Available nitrogen $(\mathrm{N})$ was estimated using the alkaline permanganate method of Subbiah and Asija [30], and the available phosphorus ( $\mathrm{P}$ ) was estimated by following sodium bicarbonate extraction method given by Olsen et al. [31]. Exchangeable potassium (K) was determined by Flame photometry [32]. Calcium (Ca), sulphur (S), and magnesium (Mg) contents were estimated following the procedures outlined by Jackson [33]. Available micronutrient (Zinc (Zn), Copper (Cu), Manganese ( $\mathrm{Mn}$ ) and, Boron (B)) concentrations were determined by the DTPA-TEA method [34].

\section{Soil biological analysis}

All soil biological parameters were analyzed at the peak boll formation stage (100 days after sowing). For analysis, the soil samples in triplicates were collected from the inter-planting lines at $0-30 \mathrm{~cm}$ depth from the representative treatments. Soil microbial biomass carbon (MBC) was determined using the $\mathrm{CHCl}_{3}$ fumigation-extraction method [35]. Samples of moist soil $(10 \mathrm{~g})$ were used in duplicate, and $\mathrm{K}_{2} \mathrm{SO}_{4}$ - extractable $\mathrm{C}$ was determined using the dichromate digestion. Microbial biomass carbon was calculated using the equation Biomass $\mathrm{C}=2.64 \mathrm{EC}$ (extractable carbon), where $\mathrm{EC}=\left(\right.$ organic $\mathrm{C}$ in $\mathrm{K}_{2} \mathrm{SO}_{4}$ from fumigated soil) - (organic $\mathrm{C}$ in $\mathrm{K}_{2} \mathrm{SO} 4$ from unfumigated soil). The soil dehydrogenase activity (DHA) was determined by the colorimetric measurement of the reduction of 2,3,5-triphenyltetrazolium chloride to triphenylformazan according to the method of Casida et al. [36]. The activities of alkaline phosphatases (ALP) and $\beta$-glucosidase (BG) were assayed according to Tabatabai [37].

\section{Yield and fibre quality analysis}

The cotton growth and yield-contributing parameters were evaluated in terms of plant height, number of sympodia, monopodia, boll numbers, boll weight, seed cotton yield, and ginning out turn percentage. The fibre quality parameters such as staple length, fibre strength, and micronaire were estimated using high volume instrument (HVI) at Ginning Training Centre (GTC) of ICAR-CIRCOT, Nagpur.

\section{Statistical analysis}

The experiment was arranged in a two-factorial randomized block design. The triplicate sets of data for the various cotton yield contributing factors, fibre quality attributes, soil biological activities, and soil nutrient availability were analyzed by two-factorial analysis, using statistical program WASP version 2.0 (Web Agri Stat Package, Indian Council of Agricultural Research, India). The single means were differentiated by Tukey's honestly significant difference (HSD) test at $p \leq 0.05$ and designated using lowercase alphabets for the pooled data. The least significant difference (LSD) was calculated at the level of $0.05 \%$ for each main/sub-treatment and their interactions.

\section{Results And Discussion}

\section{Cotton stalk compost and microbial seed treatment on cotton yield contributing parameters}

Cotton has two branching patterns: monopodial (vegetative branches) and sympodial (fruiting or boll-bearing branches). Sympodia are of great importance in cotton, as it determines the number of inflorescences and bolls, which contributes to the final seed cotton yield. The nutrient management practices and microbial seed treatment significantly $(p<0.05)$ influenced the number of sympodial branches formed in the cotton. A $0.6 \%$ increase in sympodia was observed in microbial consortia seed treatment compared to cotton seeds without microbial seed treatment. Among the nutrient management treatments, INM 
and MINM recorded 2\% more sympodial branches than the standard RDF. However, the treatments that received only FYM and ECC (17.9) recorded significantly fewer sympodia than RDF (Fig. 1a). Overall, the number of sympodia among the nutrient management treatments (INM, MINM, and RDF) did not differ significantly. More harvestable bolls were recorded in the INM and MINM treatments compared to the RDF. The INM and MINM were found to have an equivalent number of bolls. Similarly, the treatments, which received microbial consortia seed treatment, recorded $8.9 \%$ increase in boll numbers per plant compared to cotton seeds without microbial seed treatment (Fig. 1b). The FYM and ECC treatments recorded significantly lesser boll numbers compared to RDF. Overall, our results indicate that ECC can act as an effective substitute for FYM in INM practice for cotton production.

The MINM treatment recorded higher boll weight compared to the INM and RDF, which was approximately $9.9 \%$ more than those of the RDF. Further, a $17.6 \%$ increase in boll weight was observed in the treatment of cotton seeds with microbial consortia compared to the untreated (Fig. 1c). Although, there were variations in the SCY over the years, treating cotton seeds with microbial consortia increased SCY by $12.8 \%$ compared to untreated seeds. The treatment, which received microbial seed treatment, recorded a SCY of $2815 \mathrm{~kg} \mathrm{ha}^{-1}$ compared to $2496 \mathrm{~kg} \mathrm{ha}^{-1}$ in untreated seed plot (Fig. $1 \mathrm{~d}$ ). Averaged over the years, INM (3344 $\left.\mathrm{kg} \mathrm{ha}^{-1}\right)$ followed by MINM (3190 $\left.\mathrm{kg} \mathrm{ha}^{-1}\right)$ recorded significantly higher SCY than RDF (2835 $\left.\mathrm{kg} \mathrm{ha}^{-1}\right)$, which were $18 \%$ and $13 \%$ more than the RDF, respectively. The INM and MINM found to be on par in the SCY according to the HSD test. The sole application of FYM and ECC application showed a non-significant effect on sympodia, boll numbers, boll weight, and SCY over RDF.

The higher fruiting branches, boll numbers, boll weight and SCY in INM and MINM treatments along with microbial seed treatments indicate favorable conditions in those treatments in terms of modulation of soil physical, chemical and biological properties. The cotton yield contributing parameters are greatly influenced by soil moisture, stress conditions, pest and disease, and nutrient availability, apart from genetic differences in cotton variety or hybrid. The higher boll numbers and SCY in INM and MINM are additionally attributed to the seed inoculated microbial consortia, which have mobilized or solubilized the unavailable nutrients in soil to plant available form, apart from the production of plant growth hormones and other stress alleviators. Further, the nutrient content of FYM in INM and ECC in MINM has played a major role in enhancing soil physical (reduction in soil bulk density facilitating deeper root penetration) and chemical properties (decline in soil pH promoting higher nutrient mobilization), along with enhancement in organic carbon and other macro, secondary and micronutrient supplementation compared with RDF, which supplies only chemical form of nutrients.

In earlier studies, a significant enhancement in soil organic carbon and available nutrient status was reported with FYM application in cotton [38, 39] with increased SCY [40]. Similarly, in another field study on cotton in Vertisol, lower nutrient uptake was reported for farmer practice compared to the best agronomic management practices with inorganic nutrients [41]. The combined application of NPK fertilizer along with beneficial microorganisms, such as arbuscular mycorrhiza was reported to influence cotton growth [42]. Integrated use of organic and inorganic nutrients with effective microorganisms was shown to enhance the growth and yield of cotton, apart from saving $50 \%$ mineral nitrogen fertilizer [43]. The combined application of organic and inorganic inputs in cotton improved soil physical properties, such as a reduction in bulk density, greater water holding capacity, higher infiltration rate, and an increase in nutrient availability [44].

\section{Cotton stalk compost and microbial seed treatment on cotton fibre quality attribute}

Though cotton yield is the most important factor to consider for farmer income, the price of cotton lint is decided on the basis of its fibre qualities. Hence, fibre quality is an essential parameter in cotton production. In our study, treatment, which received microbial seed treatment, recorded significantly $(p<0.05)$ higher ginning outturn (GOT) compared with untreated (Fig. 2a). In sub-treatments, MINM followed by INM recorded significantly ( $p<0.05)$ higher GOT compared to RDF. About the fibre length, cotton seeds treated with microbial consortia recorded $1.39 \%$ increase ( $30.6 \mathrm{~mm}$ ) over the untreated seeds ( $30.2 \mathrm{~mm})$. MINM and INM recorded $31.3 \mathrm{~mm}$ and $30.6 \mathrm{~mm}$, respectively, in sub-treatments, which was 4.51 and $2.1 \%$ increase in fibre length over the RDF (29.9 mm) (Fig. $2 \mathrm{~b}$ ). Similarly, in fibre strength, MINM and INM recorded $22.3 \mathrm{~g} \mathrm{tex}^{-1}$ and $21.5 \mathrm{~g} \mathrm{tex}^{-1}$, respectively, which were 5.19 and $1.42 \%$ increase over the RDF. Microbial seed treatment significantly enhanced the fibre strength by $4.7 \%$ compared to untreated seeds (Fig. 2c). However, there was a non-significant ( $p>0.05$ ) difference in micronaire for both the main and sub-treatments (Fig. 2d). Though, the sole application of FYM and ECC was non-significant in GOT compared with RDF, they showed a significant increase in fibre length and strength over the RDF treatment. The improvement in the cotton fibre quality in INM and MINM practice compared to the RDF is ascribed to the synergistic and interactive effect of organic and chemical input on modulating the soil properties. Primarily, the enhancement in soil organic matter and associated biological activity and nutrient fluxes in soil are important factor, which have regulated the cotton fibre development. Although cotton fibre attributes largely depend on genetic control, environment and crop management greatly influence the fibre properties including length, strength and maturity [45]. Especially, water availability, nutrient deficiencies, and C availability affects the cellulose deposition in cotton during fibre development $[46,47]$

\section{Cotton stalk compost and microbial seed treatment on soil biological activities}

The microbial seed treatment significantly $(p<0.05)$ enhanced the soil microbial biomass carbon (MBC) compared to the untreated seeds. In sub-treatments, MINM followed by INM recorded a significantly $(p<0.05)$ higher MBC than RDF, which was $2.4 \%$ and $0.65 \%$ increase over the RDF for MINM and INM, respectively (Table 2). The dehydrogenase (DHA) as an indicator of soil microbial activity was significantly enhanced by microbial seed treatment (6.14 $\mu \mathrm{g}$ TPF g ${ }^{-1} \mathrm{~h}^{-1} ; 10.4 \%$ increase) compared to untreated seeds (Table 2). Similarly, the MINM and INM recorded $7.0 \mu \mathrm{g}$ and $6.3 \mu \mathrm{g}$, respectively, which were 20.4 and $8.4 \%$ increase over the RDF $(5.82 \mu \mathrm{g})$. Application of FYM and ECC alone enhanced DHA in soil over the RDF. The soil alkaline phosphatase (ALP) plays a major role in the hydrolysis of organic P substances to inorganic form, thus enhancing the phosphorus mineralization and availability in the soil. 
Table 2

Nutrient management practices on soil biological attributes

\begin{tabular}{|c|c|c|c|c|c|c|c|c|c|c|c|c|c|c|c|c|}
\hline \multirow[t]{2}{*}{ Treatments } & \multicolumn{4}{|c|}{$\begin{array}{l}\text { Microbial biomass carbon } \\
\left(\mu \mathrm{g} \mathrm{g}^{-1}\right)\end{array}$} & \multicolumn{4}{|c|}{$\begin{array}{l}\text { Dehydrogenase activity } \\
\left(\mu \mathrm{gTPF} \mathrm{g}^{-1} \mathrm{~h}^{-1}\right)\end{array}$} & \multicolumn{4}{|c|}{$\begin{array}{l}\text { Alkaline phosphatase } \\
\left(\mu \mathrm{g} P \mathrm{PN} \mathrm{g}^{-1} \mathrm{~h}^{-1}\right)\end{array}$} & \multicolumn{4}{|c|}{$\begin{array}{l}\beta \text { glucosidase } \\
\left(\mu \mathrm{g} \text { PNP g }{ }^{-1} h^{-1}\right)\end{array}$} \\
\hline & $\begin{array}{l}\text { Year- } \\
1\end{array}$ & $\begin{array}{l}\text { Year- } \\
2\end{array}$ & $\begin{array}{l}\text { Year- } \\
1\end{array}$ & Pooled & $\begin{array}{l}\text { Year- } \\
1\end{array}$ & $\begin{array}{l}\text { Year- } \\
2\end{array}$ & $\begin{array}{l}\text { Year- } \\
1\end{array}$ & Pooled & $\begin{array}{l}\text { Year- } \\
1\end{array}$ & $\begin{array}{l}\text { Year- } \\
2\end{array}$ & $\begin{array}{l}\text { Year- } \\
1\end{array}$ & Pooled & $\begin{array}{l}\text { Year- } \\
1\end{array}$ & $\begin{array}{l}\text { Year- } \\
2\end{array}$ & $\begin{array}{l}\text { Year- } \\
1\end{array}$ & Poo \\
\hline
\end{tabular}

Main

treatments

\begin{tabular}{|c|c|c|c|c|c|c|c|c|c|c|c|c|c|c|c|c|}
\hline$-(\mathrm{MC})$ & 638.5 & 648.1 & 655.8 & 647.5 & 4.88 & 5.17 & 6.63 & 5.56 & 164.8 & 181.9 & 191.2 & 179.3 & 77.3 & 86.3 & 98.7 & 87.4 \\
\hline$+(M C)$ & 648.6 & 656.4 & 669.2 & 658.1 & 5.34 & 5.66 & 7.42 & 6.14 & 174.4 & 192.2 & 206.0 & 190.9 & 86.7 & 93.0 & 108.5 & 96.1 \\
\hline $\operatorname{LSD}_{0.05}$ & 5.25 & 4.58 & 4.22 & 2.85 & 0.27 & 0.26 & 0.29 & 0.19 & 2.64 & 2.05 & 3.00 & 1.54 & 2.01 & 3.30 & 3.22 & 1.79 \\
\hline
\end{tabular}

Sub

treatments

\begin{tabular}{llllllllllllllllll} 
RDF & 647.8 & 652.1 & 666.5 & $655.5^{\mathrm{b}}$ & 5.08 & 5.33 & 7.04 & $5.82^{\mathrm{c}}$ & 172.6 & 178.5 & 193.2 & $181.4^{\mathrm{b}}$ & 95.8 & 90.3 & 99.7 & 95.3 \\
\hline INM & 652.5 & 656.6 & 670.3 & $658.9^{\mathrm{b}}$ & 5.24 & 6.02 & 7.66 & $6.31^{\mathrm{b}}$ & 175.5 & 200.2 & 215.9 & $197.2^{\mathrm{a}}$ & 91.4 & 96.5 & 114.0 & 100. \\
\hline MINM & 661.0 & 671.4 & 681.9 & $671.4^{\mathrm{a}}$ & 6.16 & 6.36 & 8.50 & $7.01^{\mathrm{a}}$ & 181.5 & 212.4 & 219.7 & $204.5^{\mathrm{a}}$ & 97.8 & 102.1 & 125.4 & 108. \\
\hline Only FYM & 649.2 & 662.8 & 667.1 & $659.7^{\mathrm{b}}$ & 5.50 & 5.75 & 7.55 & $6.27^{\mathrm{bc}}$ & 170.6 & 184.2 & 201.1 & $185.3^{\mathrm{b}}$ & 85.8 & 92.8 & 105.2 & 94.6 \\
\hline Only ECC & 652.1 & 653.6 & 667.4 & $657.7^{\mathrm{b}}$ & 5.24 & 5.37 & 7.32 & $5.97^{\mathrm{c}}$ & 164.3 & 186.3 & 194.6 & $181.7^{\mathrm{b}}$ & 75.8 & 90.9 & 103.1 & 89.9 \\
\hline Control & 598.7 & 617.5 & 621.6 & $612.6^{\mathrm{c}}$ & 3.42 & 3.66 & 4.09 & $3.2^{\mathrm{d}}$ & 153.3 & 160.8 & 167.2 & $160.4^{\mathrm{c}}$ & 55.5 & 65.2 & 74.2 & 65.0
\end{tabular}

(No

nutrients)

\begin{tabular}{|c|c|c|c|c|c|c|c|c|c|c|c|c|c|c|c|c|}
\hline $\mathrm{LSD}_{0.05}$ & 6.69 & 7.93 & 7.31 & 4.94 & 0.48 & 0.46 & 0.50 & 0.32 & 4.58 & 3.56 & 5.20 & 2.67 & 3.49 & 5.72 & 5.57 & 3.10 \\
\hline nteraction & 9.46 & 11.2 & 10.3 & 6.99 & 0.67 & 0.65 & 0.71 & 0.46 & 6.48 & 5.04 & 7.36 & 3.78 & 4.93 & 8.09 & 7.88 & 4.38 \\
\hline
\end{tabular}

(Main $\mathrm{x}$

Sub)

$\mathrm{LSD}_{0.05}$

All values are mean of three replications; - (MC), without microbial consortia seed treatment, $+(\mathrm{MC})$, with microbial consortia seed treatment; Values indicatin superscript letters are statistically significant according to the Tukey's honestly significant difference (HSD) test $(p<0.05)$ among the treatments.

Treating cotton seeds with microbial consortia enhanced the soil ALP activity by $6.5 \%$ compared to the untreated seed plot (Table 2 ). In sub-treatments, PINM (205 $\mu \mathrm{g} ; 13 \%$ increase) followed by INM $(197 \mu \mathrm{g} ; 8.7 \%$ increase), FYM $(185 \mu \mathrm{g})$, and ECC $(181 \mu \mathrm{g})$ recorded significantly higher ALP activity compared to the RDF $(181 \mu \mathrm{g})$. A similar trend was observed for the $\beta$-glucosidase (BG) activity in our study. The BG is an important indicator of carbon cycling in the environment, which cleaves cellobiose into glucose molecules and subsequently available as a carbon source for microbial activities in the soil. Microbial seed treatment showed $10 \%$ increased BG activity compared to the untreated seed plot. In sub-treatments, PINM (13.8\% increase) followed by INM (5.7\% increase) recorded higher BG activity compared to the RDF (95 $\mu \mathrm{g})$ (Table 2).

Biological indicators form an integral component in soil health assessment [48]. Recently, soil health indicators such as MBC and soil enzyme activities have been used as an indicator of soil qualities under different agricultural practices $[49,50]$. Soil enzymes perform several biogeochemical reactions in soil, which plays a major role in nutrient recycling and help plants to assimilate the available nutrients [51,52]. Soil enzymes also serve as an early indicator of changes in soil, which provides information on anthropogenic impacts on soil function [53]. The increased soil biological activities in and INM and MINM treatments compared to the RDF indicate the synergistic effects of organic (FYM and ECC) and chemical fertilizers on soil physical and chemical attributes and their impact on microbial functions including microbial biomass carbon and soil enzyme activities (dehydrogenase, alkaline phosphatase, and $\beta$-glucosidase).

The increased MBC in treatments that received organic (FYM and ECC) and organic plus chemical inputs (INM and MINM) is attributed to the higher cotton root volume and rhizodeposition than treatments, which received only chemical fertilizer (RDF) or organics (FYM and ECC). Possibly, the readily metabolizable carbon from organics and nutrient supply from chemical fertilizer at cotton rhizosphere and the differences in root exudates due to nutrient management practices are the influential factors contributing to increased microbial colonization and subsequent higher MBC in soils under INM and MINM. MBC comprises $1-4 \%$ of soil organic matter [54] and is the most active component of soil organic carbon that regulates biogeochemical processes in terrestrial ecosystems [55]. MBC is considered as a robust indicator of soil quality as it responds to environmental changes, much earlier than bulk soil organic matter. The decrease of $\mathrm{MBC}$ as a fraction of total organic carbon implies a reduction in microbial transformation and intensity [56]. However, long-term experiments in Vertisols demonstrated mineral fertilizer application sequestered higher organic C compared with the application of FYM alone [57]. Further, long-term applications of organic and inorganic supplement aid in the accumulation of organic matter, which in turn had substantial incremental effect on the soil microbial biomass and its activities [58]. Goyal et al. [59] showed that the application of inorganic fertilizers increased soil MBC by increasing root growth, root exudates, and production of mucigel over unfertilized fields in sandy loam soil. They attributed the increase in MBC to increased root growth, root exudates, 
mucigel and sloughed-off cells. The FYM and inorganic fertilizers have been reported to have both positive and negative effects on MBC and microbial activities [60]. Studies have shown that application of organics, including FYM and NPK fertilizer had significantly increased the organic carbon and microbial biomass $[61,62]$.

The higher DHA in INM and MINM treatments is mainly attributed to the higher microbial activity stimulated by the increased root density and subsequent higher root exudation in cotton than RDF or FYM/ECC alone. Among the soil enzymes, dehydrogenase activity is considered an indicator of microbial oxidative activity as it occurs only in the viable cells, and frequently correlates with respiratory activity in soil [63]. Positive correlations between DHA and Bt-cotton cultivation are well documented [64,65]. DHA in soil is reported to largely depend on the soluble organic C content [66], and the application of organic manures to soils is reported to significantly increase DHA activity [67]. However, DHA varies due to soil properties, including soil aeration and water availability [68].

Soil phosphatase plays a major role in the mineralization of organic $\mathrm{P}$ to inorganic form, thus enhancing $\mathrm{P}$ availability in the soil for plant and microbial uptake [69]. Possibly, cotton seed inoculation with efficient phosphate solubilizing microbes along with organic and inorganic input would have accelerated the alkaline phosphatase activity and P solubilizing efficiency in the rhizosphere, enhancing cotton SCY and fibre properties. The $\beta$-glucosidase is an important indicator of carbon cycling in the environment, which degrades the cellulose to glucose; subsequently, enhances the bioavailability carbon in the soil for microbial activities [70]. The increased BG activity in the INM and MINM indicates efficient carbon cycling in those treatments compared with RDF. The FYM and ECC supplementation with chemical fertilizer has enhanced the BG activity and subsequent carbon mineralization.

\section{Cotton stalk compost and microbial seed treatment on soil nutrient availability}

Treating cotton seed with microbial consortia found to reduce the soil pH by one unit (7.27) compared to untreated seed plot (7.38). In sub-treatments, FYM, INM, and MINM decreased the soil pH by $4.3 \%$ and $3.3 \%$, respectively, compared to the initial soil pH (7.54) (Table 3). The soil bulk density (BD) found to get reduced by microbial seed treatment as that of untreated. The INM, MINM, and FYM treatment showed on par reduction in soil BD, which amounts to 6.9-8.0\% reduction in $\mathrm{BD}$ compared to the initial soil $\mathrm{BD}$ (Table 3). Though the calcium carbonate $\left(\mathrm{CaCO}_{3}\right)$ is essential for soil-buffering and soil binding (soil structure), excess soil $\mathrm{CaCO}_{3}$ can induce sodicity, which affects soil properties including drainage, infiltration rate, nutrient availability, and crop productivity. Treating cotton seed with microbial consortia found to reduce $\mathrm{CaCO}_{3} \%$ by $0.4 \%$ compared to untreated seed plots. The INM and $\mathrm{MINM}$ reduced the soil CaCO 3 , by $3.0 \%$ and $2.6 \%$, respectively compared to the initial soil $\mathrm{CaCO}_{3}$ (Table 3). The soil organic carbon (OC) content was increased by $3.8 \%$ through microbial seed treatment compared to untreated seed plot. Similarly, in the sub-treatments, the INM, MINM, and FYM showed on par results in the enhancement of OC, which amounts to 19 to $21 \%$ increase in OC compared to the initial soil OC. 
Table 3

Nutrient management practices on soil nutrient availability after three years of experimentation

\begin{tabular}{|c|c|c|c|c|c|c|c|c|c|c|c|c|c|c|}
\hline Treatments & $\mathrm{pH}$ & BD & $\mathrm{CaCO}_{3}$ & OC & $\mathbf{N}$ & $\mathbf{P}$ & $\mathrm{K}$ & $\mathrm{Ca}$ & $\mathrm{S}$ & $\mathrm{Mg}$ & $\mathrm{Zn}$ & $\mathrm{Cu}$ & Mn & Bo \\
\hline Initial values & 7.54 & 1.87 & 7.58 & 4.8 & 176 & 14.5 & 503 & 48.27 & 0.64 & 17.62 & 0.40 & 1.61 & 13.83 & 1.29 \\
\hline \multicolumn{15}{|c|}{ Main treatments } \\
\hline$-(\mathrm{MC})$ & 7.38 & 1.78 & 7.48 & 5.3 & 198.5 & 20.6 & 542.4 & 50.3 & 0.79 & 22.3 & 0.66 & 2.17 & 14.5 & 2.11 \\
\hline$+(\mathrm{MC})$ & 7.27 & 1.75 & 7.45 & 5.5 & 209.0 & 22.5 & 555.6 & 52.3 & 0.87 & 24.5 & 0.71 & 2.20 & 15.0 & 2.24 \\
\hline $\operatorname{LSD}_{0.05}$ & 0.006 & 0.006 & 0.007 & 0.05 & 0.588 & 0.05 & 1.043 & 0.344 & 0.007 & 0.064 & 0.006 & 0.006 & 0.023 & 0.015 \\
\hline \multicolumn{15}{|c|}{ Sub treatments } \\
\hline RDF & $7.37^{d}$ & $1.82^{\mathrm{c}}$ & $7.53^{c}$ & $5.0^{d}$ & $187.9^{e}$ & $18.5^{\mathrm{d}}$ & $536.3^{c}$ & $50.5^{\mathrm{d}}$ & $0.77^{c}$ & $21.3^{d}$ & $0.59^{d}$ & $1.65^{c}$ & $14.6^{\mathrm{c}}$ & $1.44^{\mathrm{c}}$ \\
\hline INM & $7.29^{b}$ & $1.73^{a}$ & $7.38^{b}$ & $5.8^{\mathrm{a}}$ & $225.6^{\mathrm{b}}$ & $24.4^{\mathrm{a}}$ & $577.0^{\mathrm{a}}$ & $54.4^{\mathrm{b}}$ & $1.01^{\mathrm{a}}$ & $27.6^{\mathrm{a}}$ & $0.86^{a}$ & $2.51^{\mathrm{a}}$ & $15.8^{\mathrm{a}}$ & $2.69^{a}$ \\
\hline MINM & $7.29^{b}$ & $1.72^{\mathrm{a}}$ & $7.34^{\mathrm{a}}$ & $5.8^{\mathrm{a}}$ & $231.0^{\mathrm{a}}$ & $25.1^{\mathrm{a}}$ & $574.3^{\mathrm{a}}$ & $55.0^{\mathrm{a}}$ & $1.00^{\mathrm{a}}$ & $27.1^{\mathrm{a}}$ & $0.84^{a}$ & $2.50^{\mathrm{a}}$ & $15.7^{\mathrm{a}}$ & $2.65^{a}$ \\
\hline Only FYM & $7.21^{\mathrm{a}}$ & $1.74^{\mathrm{a}}$ & $7.43^{b}$ & $5.7^{\mathrm{a}}$ & $211.0^{c}$ & $24.4^{\mathrm{b}}$ & $566.1^{\mathrm{b}}$ & $52.8^{\mathrm{C}}$ & $0.88^{\mathrm{b}}$ & $25.7^{b}$ & $0.80^{\mathrm{b}}$ & $2.53^{\mathrm{a}}$ & $15.4^{\mathrm{b}}$ & $2.61^{b}$ \\
\hline Only ECC & $7.34^{\mathrm{c}}$ & $1.76^{b}$ & $7.52^{c}$ & $5.5^{\mathrm{c}}$ & $204.0^{d}$ & $23.4^{\mathrm{c}}$ & $562.2^{\mathrm{b}}$ & $52.5^{\mathrm{c}}$ & $0.79^{c}$ & $24.2^{c}$ & $0.70^{c}$ & $2.39^{b}$ & $14.8^{\mathrm{C}}$ & $2.54^{b}$ \\
\hline $\begin{array}{l}\text { Control } \\
\text { (No nutrients) }\end{array}$ & $7.47^{\mathrm{e}}$ & $1.85^{d}$ & $7.60^{d}$ & $4.5^{\mathrm{e}}$ & $163.4^{f}$ & $13.5^{\mathrm{e}}$ & $478.3^{d}$ & $42.5^{\mathrm{e}}$ & $0.55^{\mathrm{d}}$ & $14.6^{\mathrm{e}}$ & $0.32^{\mathrm{e}}$ & $1.51^{\mathrm{d}}$ & $12.0^{\mathrm{d}}$ & $1.11^{d}$ \\
\hline $\mathrm{LSD}_{0.05}$ & 0.011 & 0.010 & 0.011 & 0.09 & 1.019 & 0.102 & 1.807 & 0.597 & 0.012 & 0.111 & 0.011 & 0.010 & 0.039 & 0.025 \\
\hline $\begin{array}{l}\text { Interaction } \\
\text { (Main x Sub) } \\
\text { LSD }_{0.05}\end{array}$ & 0.015 & 0.014 & 0.016 & 0.12 & 1.441 & 0.145 & 2.555 & 0.844 & 0.017 & 0.157 & 0.016 & 0.015 & 0.055 & 0.036 \\
\hline $\begin{array}{l}\text { All values are } \\
\text { density (BD) e } \\
\text { and Potassiun } \\
\text { and Boron (Bo } \\
\text { difference (HS }\end{array}$ & $\begin{array}{l}\text { f three } \\
\text { ed in } \mathrm{M} \\
\text { kpresse } \\
\text { ssed in } \\
(p<0 \text {. }\end{array}$ & $\begin{array}{l}\text { plicatic } \\
\mathrm{m}^{-3} ; \mathrm{C} \\
\text { in } \mathrm{kg} \mathrm{h} \\
\mathrm{g} \mathrm{kg}^{-1} \\
\text { ) } \mathrm{amon}\end{array}$ & $\begin{array}{l};-(\mathrm{MC}) \\
\text {; Cam car } \\
\text { alues ir } \\
\text { he treat }\end{array}$ & $\begin{array}{l}\text { vithout r } \\
\text { nate (C } \\
\text { (Ca) ar } \\
\text { icating } \\
\text { ents. }\end{array}$ & $\begin{array}{l}\text { icrobial } \\
\mathrm{CO}_{3} \text { ) exp } \\
\text { Magnes } \\
\text { perscrip }\end{array}$ & $\begin{array}{l}\text { Isortia } \\
\text { ssed in } \\
\text { m expre } \\
\text { tters ar }\end{array}$ & $\begin{array}{l}\text { d treatn } \\
\text { soil org } \\
\text { ed in cn } \\
\text { tatistic }\end{array}$ & $\begin{array}{l}\mathrm{nt},+(\mathrm{M} \\
\mathrm{c} \text { carbo } \\
\left(\mathrm{p}^{+}\right) \mathrm{kg} \\
\text { signifi }\end{array}$ & $\begin{array}{l}\text { with r } \\
\text { OC) e } \\
\text {; Sulpl } \\
\text { tt acc }\end{array}$ & $\begin{array}{l}\text { robial c } \\
\text { essed in } \\
\text { (S), Zin } \\
\text { ing to th }\end{array}$ & $\begin{array}{l}\text { sortia } \\
\mathrm{kg}^{-1} \text {; } \\
\text { Zn), C } \\
\text { Tukey' }\end{array}$ & $\begin{array}{l}\text { ed treatn } \\
\text { trogen ( } \\
\text { per (Cu), } \\
\text { onestly }\end{array}$ & $\begin{array}{l}\text { ent; pH ( } \\
\text { Phosph } \\
\text { Mangane } \\
\text { ignifican }\end{array}$ & $\begin{array}{l}\text { ); Bulk } \\
\text { us (P), } \\
\text { (Mn), }\end{array}$ \\
\hline
\end{tabular}

In primary nutrients, microbial seed treatment significantly enhanced the available $\mathrm{N}, \mathrm{P}$, and $\mathrm{K}$ by $5 \%, 9 \%$, and $2 \%$, respectively, compared to the untreated plots. Similarly, in sub-treatment plots, the MINM and showed on par resulted in the enhancement of available N, P, and K, which amounts to $20 \%-23 \%, 32 \%-36 \%$, and 7\%-7.5\% increase in N, P, and K compared to the initial soil N, P, and K, respectively (Table 3). In secondary nutrients, similar trend was observed in the enhancement of $\mathrm{Ca}, \mathrm{S}$, and $\mathrm{Mg}$. Microbial seed treatment significantly enhanced $\mathrm{Ca}$, S, and $\mathrm{Mg}$ by $4 \%, 10 \%$, and $9.9 \%$, respectively, compared to the untreated plots (Table 3). In sub-treatment plots, the MINM and INM showed on par results in the enhancement of secondary nutrients, which amounts to $7.7 \%-8.9 \%$, $30 \%-31 \%$, and $27 \%-30 \%$ increase in the $\mathrm{Ca}, \mathrm{S}$, and $\mathrm{Mg}$ content compared to the initial soil $\mathrm{Ca}, \mathrm{S}$, and $\mathrm{Mg}$ content, respectively (Table 3 ). In addition to INM and MINM, the FYM and ECC application significantly enhanced secondary nutrient availability compared with RDF as well the initial soil values.

Microbial seed treatment significantly enhanced the micronutrient availability by $7.6 \%$ for $\mathrm{Zn}, 1.3 \%$ for $\mathrm{Cu}, 3.5 \%$ for $\mathrm{Mn}$, and $6 \%$ for Bo compared to the untreated plots (Table 3). In sub-treatment, the MINM and INM showed on par results in the enhancement of micronutrients, which amounts to $42 \%-46 \%$, $51 \%-52 \%, 7.5 \%-8.2 \%$, and $84 \%-87 \%$ increase in $\mathrm{Zn}, \mathrm{Cu}, \mathrm{Mn}$, and Bo compared to the initial soil $\mathrm{Zn}, \mathrm{Cu}, \mathrm{Mn}$, and Bo contents, respectively. Application of $\mathrm{FYM}$ and ECC also significantly enhanced the micronutrient availability compared with RDF and the initial soil test values.

Enhancement and protection of soil health is essential to the sustainability of agriculture [71]. Under the pressure of increasing food, fodder, feed, fibre and fuel production, soil has been used as a substrate for plant growth with substantial dependence on an external supply of plant nutrients (organic or inorganic). Soils of various agro-ecological zones have developed exhaustion with declining productivity, predominantly of plant nutrients due to non-replenishment of essential nutrients [72]. Though, the application of organic manure is recommended in agriculture, due to its non-availability, most farmers depend solely on chemical fertilizers, which in long-run affects soil health and crop productivity. In agriculture, the application of compost is reported to have longer-lasting effects on soil health improvement compared to residue or manure application directly, as the former contain highly degraded organic material with readily available nutrients supports plant growth [73]. Further, nutrient release from matured compost is faster and effective to adjacent rhizosphere enhancing microbial activity compared to the direct incorporation of crop residues in soils [74]. Additionally, integrated use of organic and inorganic nutrient sources with microbial seed inoculation is expected to modulate the soil physical and chemical properties, accelerating the microbial activity in the rhizosphere resulting in enhanced crop growth and soil health, compared to either organic or chemical input alone. The role of integrated nutrient management in enhancing soil quality has been reported by several authors [75]. Several studies have shown that the integration of plant beneficial microorganisms as seed treatment and soil application in INM can synergistically enhance crop and soil productivity [76, 77].

\section{Economics of cotton stalk compost vis-à-vis farmyard manure application in Bt-cotton production}


There was a saving of US\$15.06 in the INM and MINM treatments over RDF treatment. Furthermore, the FYM that is in short supply entails an expenditure of US\$ $34.24 \mathrm{ha}^{-1}$. Substitution of ECC in the MINM treatment saved a sum of US\$23.24 ha $\mathrm{h}^{-1}$ including the ECC production cost of US\$ 11.0 (Table 4 ).

Fertilizers and manures are the essential agri-inputs contributing to $9.55 \%$ and $3.2 \%$, respectively to the total cost cultivation in cotton in India [7]. However, the cultivation of high yielding hybrids with greater nutrient demand [78] and decline in fertilizer productivity contributed to an increase in the amounts of fertilizer use in cotton production [79]. Our study, demonstrates the potential saving on fertilizers and manure costs through substitution of FYM with ECC by recycling cotton stalks, which are otherwise brunt off as waste material. Utilizing ECC would benefit the poor and marginal farmers by reducing the cost of cultivation. Moreover, $50 \%$ reduction in nitrogenous, phosphatic, and potassic fertilizers would reduce the environmental foot print.

Table 4

Economic viability of enriched cotton stalk compost vis-à-vis farmyard manure application in Bt-cotton production

\begin{tabular}{|c|c|c|c|}
\hline $\begin{array}{l}\text { Inorganic nutrients/manures } \\
\text { (US\$) }\end{array}$ & RDF & INM & MINM \\
\hline Urea & 14.63 & 9.75 & 9.75 \\
\hline Single super phosphate & 14.79 & 9.98 & 9.98 \\
\hline Muriate of potash & 16.64 & 11.27 & 11.27 \\
\hline Farmyard manure & - & 34.24 & - \\
\hline ECC production cost & - & - & 11.00 \\
\hline Cost of NPK + manure & 46.00 & 65.24 & 42.00 \\
\hline
\end{tabular}

\section{Conclusions}

Our study indicates the potential of using enriched cotton stalk compost (ECC) as a substitute for farmyard manure (FYM) in the recommended INM practice for cotton grown on Vertisols. The sole and combined application of ECC along with the inorganic fertilizer produced a similar effect as that of FYM in enhancing cotton yield and fibre quality, in addition to improving soil properties including nutrient availability, indicating a lesser dependency on FYM as a sole organic component in the current INM practiced for cotton. The interaction between microbial consortia as seed treatment along with ECC or FYM and inorganic nutrients during cotton development found to be synergistic and beneficial in significant enhancement in cotton yield, fibre qualities, soil nutrient availability, and soil biological activity, as compared to their sole application (ECC, FYM, RDF or microbial consortia alone). Production and application of ECC at the on-farm level is estimated to reduce the costs incurred on the FYM by US\$ $34 \mathrm{ha}^{-1}$. This is the first report, which demonstrates the utility of cotton stalk compost as an alternative to farmyard manure in Bt-cotton production, without affecting the cotton yield, fibre quality, nutrient availability, and soil biological activities in vertisols. More intensive studies are necessary to provide a better understanding of the usefulness of ECC as an alternative to FYM on carbon sequestration potential, soil health and farm profitability. Further, creating mass awareness of cotton waste management at on-farm level and studies on in situ cotton stalk composting must be intensified to understand the potential of cotton stalks as organic manure in cotton production.

\section{Declarations}

\section{Acknowledgements}

We acknowledge with gratitude the support provided by the Directors of Indian Council of Agricultural Research (ICAR)-Central Institute for Cotton Research (CICR), Nagpur, Maharashtra, India and ICAR- Central Institute for Research on Cotton Technology (CIRCOT), Mumbai, Maharashtra, India.

\section{Credit Author statement}

Conceptualization and methodology: K. Velmourougane; Experiment performance, K. Velmourougane, A. Manikandan, and V. Mageshwaran; Data handling and analysis: K. Velmourougane, Blaise. D; Writing of original draft, K. Velmourougane, Blaise. D; writing, reviewing, and editing, K. Velmourougane, Blaise. D.

\section{Funding}

The authors are thankful to the ICAR-Central Institute for Cotton Research, Nagpur for providing financial support under the institute project "Evaluation of bioenriched compost on growth and yield of cotton".

\section{Conflicts of interest}

The authors declare that they have no conflicts of interest.

Ethics approval: Not applicable

Consent to participate: Not applicable

Availability of data and material: Not applicable 


\section{References}

1. Bhattacharjya, S., Sahu, A., Manna, M.C., Patra, A.K.: Potential of surplus crop residues, horticultural waste and animal excreta as a nutrient source in the central and western regions of India. Curr. Sci. 116, 1314-1323 (2019)

2. Kuna, E., Behling, R., Valange, S., Chatel, G., Colmenares, J.C.: Sonocatalysis: A potential sustainable pathway for the valorization of lignocellulosic biomass and derivatives. In: Lin, C. (eds) Chemistry and chemical technologies in waste valorization, pp. 1-20. Topics in current chemistry collections. Springer, Cham (2017).

3. Blaise, D., Ravindran, C.D.: Influence of tillage and residue management on growth and yield of cotton grown over 5 years in a semi-arid region of central India. Soil Tillage Res. 70, 163-173 (2003)

4. Jamali, M., Bakhshandeh, E., Yaghoubi Khanghahi, M., Crecchio, C.: Metadata analysis to evaluate environmental impacts of wheat residues burning on soil quality in developing and developed countries. Sustainability 13, 6356 (2021)

5. Ray, S.K., Bhattacharyya, T., Reddy, K.R., Pal, D.K., Chandran, P., Tiwary, P., et al.: Soil and land quality indicators of the Indo-Gangetic Plains of India. Curr. Sci. 107, 1470-1486 (2014)

6. Blaise, D., Ravindran, C.D., Singh, J.V.: Trends and stability analyses to interpret results of long-term effects of application of fertilizers and manure to rainfed cotton. J. Agronomy Crop Sci. 192, 319-330 (2006)

7. Reddy, A.R., Blaise, D., Anuradha, N.: Cost escalation in cotton cultivation: An analysis. Econ. Aff. 63, 833-838 (2018)

8. Bhattacharyya, T., Sarkar, D., Ray, S.K., Chandran, P., Pal, D.K., Mandal, D.K., et al.: Soil information system: Use and potentials in humid and semi-arid tropics. Curr. Sci. 107, 1550-1564 (2014a)

9. Sidhu, G.S., Bhattacharyya, T., Sarkar, D., Ray, S.K., Chandran, P., Pal, D.K., et al.: Impact of management levels and land-use changes on soil properties in rice-wheat cropping system of the Indo-Gangetic Plains. Curr. Sci. 107, 1487-1501 (2014)

10. Mandal, C., Mandal, D.K., Bhattacharyya, T., Sarkar, D., Pal, D.K., Prasad, J., et al.: Revisiting agro-ecological sub-regions of India - A case study of two major food production zones. Curr. Sci. 107, 1519-1536 (2014)

11. Velmourougane, K., Blaise, D.: Soil Health, Crop Productivity and Sustainability Challenges. In: Bhat, R. (ed.) Sustainability challenges in the agrofood Sector, pp. 509-531. John Wiley \& Sons Ltd (2017)

12. Sayara, T., Basheer-Salimia, R., Hawamde, F., Sánchez, A.: Recycling of organic wastes through composting: Process performance and compost application in agriculture. Agronomy 10, 1838 (2020)

13. Isci, A., Demirer, G.N.: Biogas production potential from cotton wastes. Renew. Energy. 32, 750-757 (2007)

14. Mandhyan, P.K., Patil, P.G., Sankaranarayanan, K., et al.: Cotton value chain, Cotton Res. J. 7, 17-35 (2016)

15. Sharma-Shivappa, R.R., Chen, Y.: Conversion of cotton wastes to bioenergy and value-added products. Trans. ASABE. 51, 2239-2246 (2008)

16. Zhang, P.P., Xu, S.Z., Zhang, G.J., Pu, X.Z., Wand, J., Zhang, W.: Carbon cycle in response to residue management and fertilizer application in a cotton field in arid Northwest China. J. Integr. Agric. 18, 1103-1119 (2019)

17. Balasubramanya, R.H., Shaikh, A.J., Sreenivasan, S.: Cotton crop and industry waste. In: Chadha, K.L., Swaminathan, M.S. (eds.) Environment and agriculture, Malhotra Publishing House, New Delhi (2008)

18. Jain, N., Bhatia, A., Pathak, H.: Emission of air pollutants from crop residue burning in India. Aerosol Air Qual. Res. 14, 422-430 (2014)

19. Guo, X. xia, Liu, H. tao, Zhang, J.: The role of biochar in organic waste composting and soil improvement: A review. Waste Manag. 102, 884-899 (2020)

20. Zhao, Z., Zhang, C., Li, F., Gao, S., Zhang, J.: Effect of compost and inorganic fertilizer on organic carbon and activities of carbon cycle enzymes in aggregates of an intensively cultivated Vertisol. PLoS One 15, (2020)

21. Hulugalle, N.R., Scott, F.: A review of the changes in soil quality and profitability accomplished by sowing rotation crops after cotton in Australian Vertosols from 1970 to 2006. Aust. J. Soil Res. 46, 173-190 (2008)

22. Sandell, G.R., Hopf, J., Chen, G., Yusaf, T.: The feasibility and development of alternative energy sources for cotton. National Centre for Engineering in Agriculture, Publication 1004527/1, USQ, Toowoomba (2014)

23. Ghosh, S., Hulugalle, N., Lockwood, P., Daniel, H., Mccorkell, B.E.: Applying composted cotton gin trash to a vertisol in southeastern queensland, Australia. Commun. Soil Sci. Plant Anal. 42, 1855-1861 (2011)

24. Egbuta, M.A., McIntosh, S., Waters, D.L.E., Vancov, T., Liu, L.: Biological importance of cotton by-products relative to chemical constituents of the cotton plant. Molecules 22, (2017)

25. Mageshwaran, V., Kathe, A.A., Ashtaputre, N.M. et al.: Accelerated process for the preparation of bioenriched compost from cotton plant stalks, Cotton Res. J. 4, 104-113 (2013)

26. Velmourougane K, Prasanna R, Chawla G, Nain L, Kumar A, Saxena AK. Trichoderma-Azotobacter biofilm inoculation improves soil nutrient availability and plant growth in wheat and cotton. J. Basic Microbiol. 59, 632-644 (2019)

27. Aasfar, A., Bargaz, A., Yaakoubi, K., Hilali, A., Bennis, I., Zeroual, Y., Meftah Kadmiri, I.: Nitrogen fixing Azotobacterspecies as potential soil biological enhancers for crop nutrition and yield stability. Microbiol. 12, 628379 (2021)

28. Klute, A., Dirksen, C.: Hydraulic conductivity diffusivity: Laboratory methods. In: Klute, A. (ed.) Methods of soil analysis, Part 1: Physical and Mineralogical Methods, 2nd Edition, Agronomy Monograph No. 9, pp. 687-734. ASA, Madison, WI (1986)

29. Richards, L.A.: Diagnosis and improvement of saline and alkali soils. USDA Agriculture Handbook 60, Washington, DC (1954) 
30. Subbiah B V, Asija G L: A rapid procedure for the determination of available nitrogen in soils. Curr. Sci. 25, 259-260 (1956)

31. Olsen, S.R., Cole, C.V., Watanabe, F.S., Dean, L.A.: Estimation of available P. USDA. Circular 939, 1-19 (1954)

32. Jankowski, S.J., Freiser, H.: Flame photometric methods of determining the Potassium Tetraphenylborate. Anal. Chem. 33, 773-775 (1961)

33. Jackson, M.L.: Soil chemical analysis. Prentice-Hall of India Pvt. Ltd, New Delhi (1973)

34. Lindsay, W.L., Norvell, W.A.: Development of a DTPA Soil Test for Zinc, Iron, Manganese, and Copper. Soil Sci. Soc. Am. J. 42, 421-428 (1978)

35. Vance, E.D., Brookes, P.C., Jenkinson, D.S.: An extraction method for measuring soil microbial biomass C. Soil Biol. Biochem. 19, 703-707 (1987)

36. Casida, L.E., Klein, D.A., Santoro, T.: Soil dehydrogenase activity. Soil Sci. 98, 371-376 (1964)

37. Tabatabai, M.A.: Soil enzymes. In: Weaver, R.W. et al. (eds.) Methods of soil analysis: Part 2. Microbiological and biochemical properties of soils, pp. 775833. Soil Science Society of America, Madison (1994)

38. Blaise, D., Rupa, T.R., Bonde, A.N.: Effect of organic and modern method of cotton cultivation on soil nutrient status. Commun. Soil Sci. Plant Anal. 35, 1247-1261 (2004)

39. Das, A., Prasad, M., Shivay, Y.S., Subha, K.M.: Productivity and sustainability of cotton (Gossypium hirsutum)-wheat (Triticum aestivum L.) cropping system as influenced by prilled urea, farmyard manure and Azotobacter. J. Agron. Crop Sci. 190, 298-304 (2004)

40. Blaise, D., Ravindran, C.D., Singh, J.V.: Trends and stability analyses to interpret results of long-term effects of application of fertilizers and manure to rainfed cotton. J. Agronomy Crop Sci. 192, 319-330 (2006)

41. Blaise, D., Bonde, A.N., Chaudhary, R.S.: Nutrient uptake and balance of cotton + pigeonpea strip intercropping on rainfed vertisols of central India. Nutr. Cycl. Agroecosystems. 73, 135-145 (2005)

42. Sridevi, S., Ramakrishnan, K.: The effect of NPK fertilizer and AM fungi on the growth and yield of cotton (Gossypium hirsutum) Var. LRA 5166. Recent Res. Sci. Technol. 2, 39-41 (2010)

43. Khaliq, A., Abbasi, M.K., Hussain, T.: Effects of integrated use of organic and inorganic nutrient sources with effective microorganisms (EM) on seed cotton yield in Pakistan. Bioresour. Technol. 97, 967-972 (2006)

44. Vora, V.D., Rakholiya, K.D., Rupapara, K. V., Sutaria, G.S., Akbari, K.N.: Effect of integrated nutrient management on Bt cotton and post harvest soil fertility under dry farming agriculture. Asian J. Agric. Res. 9, 350-356 (2015)

45. Bradow, J.M., Davidonis, G.H.: Effects of environment on fiber quality. In: Stewart, J.M., Oosterhuis, D.M., Heitholt, J.J., Mauney, J.R. (eds.) Physiology of cotton. pp. 229-245. Springer, Dordrecht (2010)

46. Constable, G.A., Bange, M.P.: Producing and preserving fiber quality: from the seed to the bale. In: World Cotton Research, 4. Lubbock,Texas (2007)

47. Girma, K., Teal, R.K., Freeman, K.W., Boman, R.K., Raun, W.R.: Cotton lint yield and quality as affected by applications of N, P, and K fertilizers. J. Cotton Sci. 11, 12-19 (2007)

48. Ritz, K., Black, H.I.J., Campbell, C.D., Harris, J.A., Wood, C.: Selecting biological indicators for monitoring soils: A framework for balancing scientific and technical opinion to assist policy development. Ecol. Indic. 9, 1212-1221 (2009)

49. Vallejo, V.E., Roldan, F., Dick, R.P.: Soil enzymatic activities and microbial biomass in an integrated agroforestry chronosequence compared to monoculture and a native forest of Colombia. Biol. Fertil. Soils. 46, 577-587 (2010)

50. Velmourougane, K., Sahu, A.: Impact of transgenic cottons expressing cry1Ac on soil biological attributes. Plant, Soil Environ. 59, 108-114 (2013)

51. Velmourougane, K., Venugopalan, M. V., Bhattacharyya, T., Sarkar, D., Ray, S.K., Chandran, P., et al.: Impacts of bioclimates, cropping systems, land use and management on the cultural microbial population in black soil regions of India. Curr. Sci. 107, 1452-1463 (2014)

52. Lupwayi, N.Z., Zhang, Y., Hao, X., Thomas, B.W., Eastman, A.H., Schwinghamer, T.D.: Linking soil microbial biomass and enzyme activities to long-term manure applications and their nonlinear legacy. Pedobiologia (Jena) 74, 34-42 (2019)

53. Nannipieri, P., Trasar-Cepeda, C., Dick, R.P.: Soil enzyme activity: a brief history and biochemistry as a basis for appropriate interpretations and metaanalysis. Biol. Fertil. Soils. 54, 11-19 (2018)

54. Anderson, T.H., Domsch, K.H.: Ratios of microbial biomass carbon to total organic carbon in arable soils. Soil Biol. Biochem. 21, 471-479 (1989)

55. Yu, H., Ding, W., Luo, J., Geng, R., Ghani, A., Cai, Z.: Effects of long-term compost and fertilizer application on stability of aggregate-associated organic carbon in an intensively cultivated sandy loam soil. Biol. Fertil. Soils. 48, 325-336 (2012)

56. Rao, D.: Microbial diversity, soil health and sustainability. J. Indian Soc. Soil Sci. 55, 392-403 (2007)

57. Wani, S.P., Pathak, P., Jangawad, L.S., Eswaran, H., Singh, P.: Improved management of Vertisols in the semiarid tropics for increased productivity and soil carbon sequestration. Soil Use Manag. 19, 217-222 (2003)

58. Chakraborty, A., Chakrabarti, K., Chakraborty, A., Ghosh, S.: Effect of long-term fertilizers and manure application on microbial biomass and microbial activity of a tropical agricultural soil. Biol. Fertil. Soils. 47, 227-233 (2011)

59. Goyal, S., Mishra, M.M., Dhankar, S.S., et al.: Microbial biomass turnover and enzyme activities following the application of farmyard manure to field soils with and without previous long-term applications. Biol. Fertil. Soils 15, 60-64 (1993)

60. Böhme, L., Langer, U., Böhme, F.: Microbial biomass, enzyme activities and microbial community structure in two European long-term field experiments. Agric. Ecosyst. Environ. 109, 141-152 (2005)

61. Ebhin Masto, R., Chhonkar, P.K., Singh, D., Patra, A.K.: Changes in soil biological and biochemical characteristics in a long-term field trial on a sub-tropical inceptisol. Soil Biol. Biochem. 38, 1577-1582 (2006)

62. Rupela, O.P., Gowda, C.L.L., Wani, S.P., Bee, H.: Evaluation of crop production systems based on locally-available biological inputs. In: Uphoff, N et al. (eds.) Biological approaches to sustainable soil systems, pp. 501-515. CRC Press, Boca Raton, Florida (2005) 
63. Nannipieri, P., Giagnoni, L., Renella, G., Puglisi, E., Ceccanti, B., Masciandaro, G., Fornasier, F., Moscatelli, M.C., Marinari, S.: Soil enzymology: Classical and molecular approaches. Biol. Fertil. Soils. 48, 743-762 (2012)

64. Singh, R.J., Ahlawat, I.P.S., Singh, S.: Effects of transgenic Bt cotton on soil fertility and biology under field conditions in subtropical inceptisol. Environ. Monit. Assess. 185, 485-495 (2013)

65. Velmourougane, K., Venugopalan, M. V., Bhattacharyya, T., Sarkar, D., Pal, D.K., Sahu, A., Ray, S.K., Nair, K.M., Prasad, J., Singh, R.S.: Soil dehydrogenase activity in agro-ecological sub regions of black soil regions in India. Geoderma 197-198, 186-192 (2013)

66. Włodarczyk, T., Stæpniewski, W., Brzezińska, M.: Dehydrogenase activity, redox potential, and emissions of carbon dioxide and nitrous oxide from Cambisols under flooding conditions. Biol. Fertil. Soils. 36, 200-206 (2002)

67. Furczak, J., Joniec, J.: Changes in biochemical activity of podzolic soil under willow culture in the second year of treatment with municipal-industrial sewage sludge. Int. Agrophysics 21, 145-152 (2007)

68. Prasad, R., Mertia, R.S.: Dehydrogenase activity and VAM fungi in tree-rhizosphere of agroforestry systems in Indian arid zone. Agrofor. Syst. 63, 219-223 (2005)

69. Margalef, O., Sardans, J., Fernández-Martínez, M., Molowny-Horas, R., Janssens, I.A., Ciais, P., Goll, D., Richter, A., Obersteiner, M., Asensio, D., Peñuelas, J.: Global patterns of phosphatase activity in natural soils. Sci. Rep. 7, (2017)

70. Błońska, E., Lasota, J.: $\beta$-Glucosidase activity of forest soil as an indicator of soil carbon accumulation. In: Soil biological communities and ecosystem resilience. pp. 253-263 (2017)

71. Bhattacharyya, T., Sarkar, D., Ray, S.K., Chandran, P., Pal, D.K., Mandal, D.K., et al.: Georeferenced soil information system: Assessment of database. Curr. Sci. 107, 1400-1419 (2014b)

72. DeLong, C., Cruse, R., Wiener, J.: The soil degradation paradox: Compromising our resources when we need them the most. Sustainability 7, $866-879$ (2015)

73. Duong, T.T.T., Penfold, C., Marschner, P.: Amending soils of different texture with six compost types: Impact on soil nutrient availability, plant growth and nutrient uptake. Plant Soil. 354, 197-209 (2012)

74. Duong, T.T.T., Verma, S.L., Penfold, C., Marschner, P.: Nutrient release from composts into the surrounding soil. Geoderma 195-196, 42-47 (2013)

75. Masmoudi, S., Magdich, S., Rigane, H., Medhioub, K., Rebai, A., Ammar, E.: Effects of compost and manure application rate on the soil physico-chemical layers properties and plant productivity. Waste Biomass Valori. 11, 1883-1894 (2020)

76. Adesemoye, A.O., Torbert, H.A., Kloepper, J.W.: Enhanced plant nutrient use efficiency with PGPR and AMF in an integrated nutrient management system. Can. J. Microbiol. 54, 876-886 (2008)

77. Kumar, A., Patel, J.S., Meena, V.S., Ramteke, P.W.: Plant growth-promoting rhizobacteria: strategies to improve abiotic stresses under sustainable agriculture. J. Plant Nutr. 42, 1402-1415 (2019)

78. Kranthi, K.R.: Cotton production systems - Need for a change in India. Cotton Statistics \& News, 38, 4-7 (2014)

79. Venugopalan, M.V., Reddy, A.R., Kranthi, K.R., Yadav, M.S., Vandana, S., Dhanashree, P.: A decade of Bt cotton in India: Land use changes and other socioeconomic consequences. In: Obi Reddy, G.P., Patil, N.G., Chaturvedi A. (eds.) Sustainable management of land resources: An Indian perspective, Apple Academic Press Inc. (2017)

\section{Figures}





Figure 1

Nutrient management practices on cotton yield contributing parameters. (-) MC, without microbial consortia seed treatment; (+) MC, with microbial consortia seed treatment; Sympodial numbers, boll numbers, and boll weights were calculated by averaging 10 plants; RDF, Recommended dose of fertilizers; INM, Integrated Nutrient Management practice; MINM, Modified Integrated Nutrient Management practice; FYM, Farm yard manure; ECC, Enriched cotton compost; MC, Microbial consortia as seed treatment. Values indicating superscript letters are statistically significant according to the Tukey's honestly significant difference $(H S D)$ test $(p<0.05)$ among the treatments. 




Figure 2

Nutrient management practices on cotton fibre quality attributes. All values are mean of three replications. (-) MC, without microbial consortia seed treatment; (+) MC, with microbial consortia seed treatment; RDF, Recommended dose of fertilizers; INM, Integrated Nutrient Management practice; MINM, Modified Integrated Nutrient Management practice; FYM, Farm yard manure; ECC, Enriched cotton compost; MC, Microbial consortia as seed treatment. Values indicating superscript letters are statistically significant according to the Tukey's honestly significant difference (HSD) test $(p<0.05)$ among the treatments.

\section{Supplementary Files}

This is a list of supplementary files associated with this preprint. Click to download.

- Graphicalabstract.eps 